\author{
УДК $78.03+785 / 781.68$ \\ DOI https://doi.org/10.31723/2524-0447-2021-32-1-19
}

\author{
Ірина Мар'янівна Шиитальна \\ ORCID: 0000-0001-8558-0259
}

аспірант кафедри історії музики та музичної етнографії

Одеської національної музичної академії імені А. В. Нежданової

iryna.shpytalna@gmail.com

\title{
АВТЕНТИЧНІСТЬ ЯК АСПЕКТ АКОРДЕОННОГО ВИКОНАВСТВА
}

Мета роботи полягає у розкритті поняття автентичності в акордеонному мистецтві як духовно-інтерпретаційному процесі, пов'язаному з особистісно-стильовими чинниками виконавської творчості, а також визначенні основних автентичних засад акордеонного виконавства, що зумовлюе симбіоз минулого та теперішнього, історичних традицій, естетично-стильових норм епохи та ціннісно-духовного особистісного розуміння виконавия. В автентично-творчому процесі виконавець проживає музичний твір у різних комунікативних ситуаціях, що приводить до постійного герменевтичного пошуку та його самоактуалізації в мистецтві. Методологія дослідження передбачає поєднання інтердисциплінарного, компаративного та праксеологічного методів, що дозволяє розширити розуміння явища автентичності як духовно-інтерпретаційного процесу акордеонної виконавської творчості, поглибити психологічне значення автентики. Наукова новизна дослідження визначається формуванням виконавських підходів до поняття автентичності, обгрунтуванням історично інформованого виконавства в акордеонній творчості. Висновки статті дозволяють визначити автентичність як основу акордеонної виконавської творчості, яка ставить складні художні завдання і творчі інтенції. Ними є цілісність когнітивного розуміння, смислу та створення живої художньої події, де виконавець стає автором. Автентичність визначається виконавським прожсиванням музичного твору, духовно-естетичною спрямованістю творчих дій та оригінальністю інтерпретації. Безумовно, кожна виконавська інтерпретація особлива, оскільки виконавець як автор та особистість посідає своє єдине та неповторне місце у творчості та житті. Все вищесказане дозволяє говорити про те, що такі творчі підходи та концепиії спрямовують на визначення явища автентичності як актуальної категорії сучасного музичного виконавства, зокрема акордеоністики як нового напряму музикознавчої науки.

Ключові слова: автентичність, виконавська інтерпретація, інтенція, історично інформоване виконавство, самоактуалізація, смисл.

(C) Шпитальна I. M., 2021 
Shpytalna Iryna Marianivna, Postgraduate Student at the Department of Music History and Musical Ethnography of the Odesa National A. V. Nezhdanova Academy of Music

\section{Authenticity as an aspect of accordion performance}

The purpose of the article is to reveal the concept of authenticity in accordion art as a spiritual-interpretive process associated with personal and stylistic factors of performance, as well as to determine the basic authentic principles of accordion performance, which determines the symbiosis of past and present, historical traditions, aesthetic and stylistic norms of the epoch and value-spiritual personal understanding of the performer. In the authentic creative process, the performer lives a piece of music in various communicative situations, which leads to a constant hermeneutic search and its self-actualization in art. The research methodology involves a combination of interdisciplinary, comparative and praxeological methods, which allows to expand the understanding of the phenomenon of authenticity as a spiritualinterpretive process of accordion performance, to deepen the psychological significance of authenticity. The scientific novelty of the research is determined by the formation of performing approaches to the concept of authenticity, substantiation of historically informed performance in accordion creativity. The conclusions of the article allow us to define authenticity as the basis of accordion performance, which sets complex artistic tasks and creative intentions. This is, first of all, the integrity of cognitive understanding, meaning and creation of a living artistic event, where the performer becomes the author. Authenticity is characterized by the performance of a musical work, the spiritual and aesthetic orientation of creative actions and the originality of interpretation. Of course, each performer's interpretation is special, because the performer as an author and a person occupies his only and unique place in art and life. All of the above suggests that these creative approaches and concepts lead to the definition of the phenomenon of authenticity as a relevant category of modern musical performance, in particular, accordion as a new direction of musicological science.

Key words: authenticity, performing interpretation, intention, historically informed performance, self-actualization, meaning.

Актуальність теми дослідження. Поняття автентичності розглядалось у багатьох гуманітарних науках, які пов'язані з дослідженням діяльності людини, іiі особистісно-ціннісними позиціями, морально-естетичними установками, духовною спрямованістю і життєвим вибором. Проблематика цього терміна була визначена в гуманістичній і трансперсональній психології, філософії, музичному мистецтві. Акордеонну виконавську творчість можна розглядати з позицій автентичності, історично інформованого виконавства, оскільки репертуарний діапазон інструмента є дуже широким (від барокової музики до модерністських напрямів сучасного мистецтва). 
Це зумовлено вдосконаленням конструктивних особливостей інструмента, його тембральним різноманіттям, динамічною градацією, що виявляється у найтонших психологічних виконавських станах.

Загалом, у виконавській творчості автентичність асоціюється з процесом ідентифікації відтворення музики минулого. Засновником руху автентичного виконавства вважається Арнольд Долмеч, який був одним з ініціаторів реконструкції старовинних інструментів та відновлення виконавських традицій. Однак інтерпретація поняття «автентичність» у цьому контексті може здаватись дещо односторонньою та відносною. Зрозуміло, що процес виконання завжди відбувається в новій комунікативній ситуації, пов'язаній з історичною дистанцією, взаємодією минулої та теперішньої духовної атмосфери, об'єктивними (сучасний інструментарій) та суб'єктивними (виконавці з особистісним баченням) змінами у творчості. 3 іншого боку, автентичне виконання виступає мімезисом, тобто наслідуванням, імітацією. Однак у розпорядженні виконавця перебуває не тільки нотний текст, а й індивідуальне ставлення до нього, тобто виконавець створює щось нове та ціннісне, хоча нерозривно пов'язане $з$ культурним надбанням минулого.

Теоретичну базу, що охоплює питання вивчення явища автентичності, становлять такі відомі представники, як Д. Бьюдженталь, К. Роджерс, А. Маслоу (психологія), М. Гайдегер, Ж.П. Сартр (філософія), Н. Арнонкур, П. Бадура-Скода, А. Долмеч, В. Ландовська, О. Любимова, М. Друскін (музичне мистецтво) та ін.

Мета статті полягає у розкритті поняття автентичності в акордеонному мистецтві як у духовно-інтерпретаційному процесі, пов'язаному з особистісно-стильовими чинниками виконавської творчості; визначенні основних автентичних засад акордеонного виконавства, що зумовлює симбіоз минулого та теперішнього, історичних традицій, естетично-стильових норм епохи та ціннісно-духовного особистісного розуміння виконавця. В автентично-творчому процесі виконавець проживає музичний твір у різних комунікативних ситуаціях, що приводить до постійного герменевтичного пошуку та його самоактуалізації у мистецтві.

Виклад основного матеріалу. Загалом, під терміном «автентичний» («справжній») можемо розуміти здатність особисто- 
сті (виконавця) до вираження цілісних емоційно-почуттєвих станів, що є обов'язковим складником продуктивної людської діяльності, зокрема виконавської. Це приводить до розуміння того, що автентичність у широкому значенні слова є психологічною основою творчого процесу, що набуває особливих форм та функцій у мистецтві.

Емоційно-чуттєва сфера породжує духовне переживання, що значно поглиблює виконавський процес, створює художню дійсність. Відомий американський дослідник Дж. Бьюдженталь уважає, що автентичність - це процес проживання власного життя. У його концепції ключовим терміном $є$ «присутність», що означає не просто фізичне перебування, а усвідомлення своєї суб'єктивності, контакт із внутрішнім життям. Додамо, що автентичність у цьому розумінні $є$ проживанням не тільки власного життя, а й музичного виконання, музичного тексту. Відомо, що виконавець не просто репрезентує нотний текст, а переживає цілісну творчу подію, виражає свій емоційно-почуттєвий стан, творчий настрій, висловлює особистісне бачення музичного твору, тобто є співавтором. Отож, кожне виконання є автентичним явищем, яке несе новий ціннісний зміст, внутрішні прагнення та духовні інтенції виконавця.

Представники гуманістичної психології та трансперсональної психології вважали, що «переживання» життєвого досвіду $€$ «переживанням власного «Я», тобто поверненням людини до iii автентичності, справжності, щирості. Виконавець є носієм творчих особистісних переживань, які об'єднуються і трансформуються у виконавський досвід. Момент проживання, переживання $є$ необхідною умовою для справжнього, щирого й душевного виконання. Г. Гадамер розглядає етимологію слова «переживати» у двох напрямах. Спочатку воно означало «бути ще живим, коли щось трапилось». Зважаючи на це, пережите - це завжди особисто пережите. Проте також використовувалась форма «пережите», яка означала збережений зміст того, що пережито. Таке значення постає як результат, який підсумовує тривалість і значення пережитої події. Так, одним 3 основних завдань виконавця є духовне й емоційне «пережиття» музичного твору, співпереживання композиторському задуму і породження нових особистісних смислів. Особистісне переживання виражається в емоційно-образній формі, тому пов'язане $з$ перетворенням емоцій і новим змістовим напов- 
ненням звукового образу. Таким чином, виконавець ідентифікує свою роль у творчому процесі, реалізує свої творчі прагнення, самоактуалізується у мистецтві.

Цікаво, що А. Маслоу визначає поняття автентичності синонімом до термінів «самоактуалізація», «ідентичність», «самореалізація», «емоційна зрілість», «індивідуалізація», «повноцінна людяність», «самовираження», «буття». Автентична особистість - це самоактуалізувальна справжня особистість, яка живе у співрозумінні зі своєю внутрішньою природою і прагне реалізувати іiі у своїй діяльності. Водночас автентичність означає здатність до усвідомлення своїх ціннісних прагнень та можливостей, розуміння власної позиції та призначення. Таким чином, автентичному виконавцеві притаманна самоактуалізація, усвідомлення власних дій у творчому процесі, зрілість емоційно-чуттєвої сфери і, що головне, гармонійне співвідношення цих процесів.

Відповідно, виконавець не тільки усвідомлює себе у творчому процесі, а й співвідносить свої переживання з композиторським задумом, узгоджує свої духовні прагнення з естетичними нормами певної епохи. К. Роджерс розкриває термін автентичності через поняття «конгруентність», позначаючи ним «узгодженість переживання, свідомості і спілкування» [10, с. 956]. У цьому контексті переживання розглядаємо як духовно-емоційне вираження виконавця, усвідомлення - як сукупність раціонально-логічних, емоційно-чуттєвих, духовних, творчих процесів; спілкування (невербальне, знакове) як виконавський спосіб передання інформації реципієнтам. Але основне місце посідає поняття узгодженості, гармонійності та естетичної цілісності минулого і теперішнього, композиторських настанов і виконавських прагнень, традицій i модифікацій, строгості та емоційності.

В аспекті сучасного акордеонного виконавства явище автентичності доцільно розглядати як духовно-інтерпретаційний процес, пов'язаний з особистісно-стильовими чинниками виконавської творчості. Безумовно, перенесення автентики в інший інструментально-органологічний простір змінює розуміння цього поняття. Зважаючи на це, можна спробувати визначити види автентики як обов'язкового складника сучасного акордеонного виконавства. Серед них:

1) знакова автентика як точне відтворення нотного тексту, що $є$ необхідним у виконавстві, зокрема у процесі адаптації 
твору для інших інструментів (перекладення/аранжування/ транскрипція);

2) змістова автентика як відповідність характеру музики, стилістично-жанрових особливостей, змісту твору, закладених композитором;

3) художня автентика як відповідність гри творчому задуму композитора, його інтенцій, прагнень, а також особистісне виконавське розуміння твору.

Так, бачимо, що автентика присутня на всіх етапах роботи над музичним твором і $є$ невід'ємним складником музичної інтерпретації (від тексту до смислу, від композитора до виконавця). Виконавець може спрямовувати творчий процес на максимальну відповідність композиторському задуму або інтерпретувати текст, спираючись на особистісне розуміння. Відповідно, автентично-творча активність виконавця може визначатись такими концепціями:

- автобіографічною, яка спрямована на втілення композиторського задуму (пов'язана з тим, що композитор завжди трансформує особисті життєві переживання у художньо-звукові; етичні вчинки - в естетичні; емпірично-практичну реальність - у художню. Посередником у цьому процесі $€$ виконавець, який переживає/співпереживає разом із композитором);

- оригінально-авторською, яка спрямована на індивідуальне бачення виконавця (визначається як власний автентичний внесок у творчому процесі виконавської інтерпретації, духовно-практичне діяння виконавця у пошуку ціннісних індивідуальних орієнтирів і їх вираження у звуковій матерії. Виконавець стає автором нових особистісних смислів та переживань; центральне місце посідає власне прочитання музичного твору, індивідуальна еманація історичних стильових ідей. У цій концепції виконавець постає автором інтерпретаціі).

Виходячи з вищесказаного, можна спробувати визначити поняття автентичності акордеонного виконавства як сукупність творчо-духовних дій, які охоплюють усвідомлення виконавських традицій (знання історично-соціальних подій епохи, композиторського стилю, умов написання музики), репрезентацію знакової системи (ії адаптацію до сучасної комунікативної ситуації), визначення особистісного виконавського ставлення до історично-ціннісного об'єкта (тексту), вираження емоційно-чуттєвого стану та настрою. Основним елементом 
таких процесів є виконавська справжність і щирість творчих дій та інтенцій. Власне кажучи, саме це наділяє кожне виконання автентичністю, оригінальністю та змістовністю.

Так, ми можемо спробувати співвіднести автентичність із взаємопов'язаними категоріями Простору, Часу і Смислу. У просторі завжди відбуваються певні події, які (як в онтологічному, так і в художньо-естетичному аспектах) пов'язані 3 особистісним переживанням/співпереживанням. Час виступає як чинник надбання творчого досвіду, який є передумовою глибинного виконавського розуміння та переживання, усвідомлення власних інтенцій у творчому процесі виконавської діяльності, тобто виконавська самоактуалізація. Смисл визначається цілісністю, що завжди пов'язана з переживанням та особистісним становленням, яке можливе тільки з досвідом. Отже, автентичне виконання передбачає розуміння історичних особливостей епохи, в якій написана музика (простір), виконавський досвід (час) і особистісне переживання виконавця (смисл).

Когнітивне засвоєння історичних особливостей епохи скеровує до терміна історично інформованого виконавства, який був широко поширеним у країнах Західної Свропи. Цей напрям актуальний для текстологічного підходу вивчення музики, зокрема музичної лексики, розкриває раціональний аспект та виконавські традиції певної епохи. Метою історично інформованого виконавства $\epsilon$ максимально близьке виконання до історичного архетипу за допомогою старовинних інструментів. Однак можемо припустити, що цей напрям не передбачає індивідуального пошуку розуміння, особистісного бачення, виконавсько-інтерпретаційного процесу, оскільки спрямований на детальне вивчення традицій, композиторської творчості шляхом систематичного наукового пошуку. Спираючись на це,, можемо спробувати розглядати поняття автентичності як більш глибинний процес виконавської творчості, який охоплює автобіографічну та оригінально-авторську концепції, а історично інформоване виконавство - як процес усвідомлення історичних традицій виконавства, пов'язаних із часовими змінами (акцентуація на автобіографічній концепціі). Так, стає зрозумілим, що автентичне виконавство має більш широке розуміння, а IIB $^{1}-$ вузьке, в центрі якого перебуває музичний текст.

1 Історично інформоване виконавство 
Історично інформоване виконавство переходить від раціонального аспекту до психологічного завдяки диригенту Теодору Курентзісу, який на прикладі власних інтерпретацій започаткував більш глибоке розуміння цього напряму.

Психологічний аспект IIB спрямовує виконавця стати автором/співавтором, «ужитись» у роль композитора, перейняти його емоційно-чуттєвий стан, максимально наблизитись до інтенціональної сторони композиторської творчості. Це так званий «духовно-інтуїтивний зв'язок», який найбільше виражається під час безпосереднього виконання, коли звукове поле композитора-виконавця-реципієнта заповнюється смисловим навантаженням та злиттям емоційної сфери. Саме так починається етап одухотворення тексту, його модифікація у живу звукову матерію. На думку приходять слова М. Бахтіна про те, що «автор виражає себе тільки через героя» [1, с. 63], де автор виступає у ролі композитора, а літературний герой трансформується у виконавця, який через історичні епохи передає композиторський задум, одухотворяючи його у сучасному часовому просторі. Однак цей процес має двосторонню спрямованість, адже виконавець так само повинен стати автором, відкрити у собі думки та прагнення композитора. Тобто виконавець виражається через автора, через композиторську творчість, а композитор - через виконавця. Таким чином, «мистецтво дає нам можливість замість одного пережити декілька життів, чим збагатити власний досвід» [1, с. 77]. У цьому контексті виконавський автентичний досвід передбачає можливість переживати концертне виконання як неповторну художню подію, яка щоразу наповнюється іншими емоційно-чуттєвими станами та смисловим навантаженням.

Якщо розглядати історично інформоване виконавство 3 психологічної точки зору, то, безумовно, ми наблизились до вищенаведеного розуміння автентичності як духовно-інтерпретаційного процесу, психологічне значення якого також залежить від виконавських інтенцій та творчих завдань (конструктивна, текстологічна, жанрово-стильова реконструкціі). Зважаючи на все вищесказане, можемо спробувати визначити декілька підходів до автентичного виконавства, а саме:

- органологічно-інструментальний (реконструкція старовинних музичних інструментів, як-от клавесин, віола да гамба, архлютня та ін. (А. Долмеч). Оскільки кожний музичний інструмент має свої технічні й звукові, артикуляційні 
особливості, то це зумовлює темброву, штрихову, артикуляційну автентики, що максимально наближує до історичного звучання твору);

- емпірично-практичний (реконструкція нотного матеріалу та його адаптація до конструктивних особливостей інструменту (акордеона) зі збереженням основних автентичних засад та виконавських традицій);

- жанрово-стильовий (реконструкція стилю в історичній дистанції/автентико-стильова інтерпретація в різних напрямах та жанрах).

Явище виконавської автентики як ціннісного нового звучання, як зазначалось вище, можна інтерпретувати з різних позицій, у різних жанрах та стилях. Безумовно, репродукція барокової музики передбачає дотримання історичних традицій виконавства, які допомагають передати дух епохи, естетичні норми і традиції. Сюди належать темброві, темпові, артикуляційно-штрихові, динамічні засоби, принципи мелодичної орнаментації. Як відомо, авторські позначення темпу, динаміки у нотних текстах цієї епохи відсутні (Urtext). Це, з одного боку, ускладнює прочитання нотного тексту і розуміння композиторського задуму, а з іншого - спрямовує до індивідуальної виконавської інтерпретації, тобто оригінальності та автентичності, адже найбільш автентичним буде таке виконання, яке досягне найвищого ціннісно-смислового вираження.

Спираючись на це, можемо спробувати визначити рівні автентичного акордеонного виконання барокової музики:

- історичний (термін Н. Арнонкура) - пошук інтерпретаційної моделі, яка передбачає максимальну відповідність естетично-стильовим традиціям цієї епохи. За В. Ландовською, таке виконання є монотонним і «приглушеним»;

- емотивно-стильовий - в основі закладені виконавські традиції, які зазнали модифікаційних процесів, пов'язаних $з$ адаптацією нотного тексту до можливостей інструмента (акордеона) та розширенням емоційно-чуттєвої сфери (у межах стилю);

- експресивний - позначений гнучкою динамікою, зміною руху, яскравою агогікою, тобто яскраво вираженою виконавською емоційністю з мінімальною відповідністю естетично-стильовим традиціям епохи.

У будь-якому разі виконання барокової музики на акордеоні вимагає трансформації тексту та його особливостей. Так, 
наприклад, виконання клавірної музики Й.С. Баха має певні технічні труднощі, серед яких такі, як обмеженість акордеонного діапазону і темброва відмінність правої та лівої клавіатур (на відміну від клавесина чи сучасного фортепіано). Незважаючи на це, втілення артикуляційно-штрихових та динамічних особливостей допомагають наблизитись до історично-естетичних норм епохи бароко, що відповідає емотивно-стильовому рівню (трансформація тексту до технічних можливостей інструменту). Але автентичність - це не тільки максимальна відповідність традиціям, а й особистісне переживання твору, формування духовної сфери виконавця. Це дозволяє розглядати автентичність у стильовому (відповідність виконання історичним традиціям), текстологічному (музичний твір виступає як автентичний феномен) та психологічно-особистісному (творча самоактуалізація виконавця) аспектах. Саме тому вагоме значення має музично-творча єдність таких аспектів у виконавському процесі.

Н. Арнонкором виокремлює два підходи до старовинної музики: перший підхід переносить іiі у сучасність, другий намагається показати іï через призму епохи, в яку вона виникла. Перший підхід пов'язаний із тим, що, на думку дослідника, музична мова завжди тісно пов'язана із сучасністю. Відомо, що мистецтво часто випереджає чи попередає певні історично-культурні події. Другий підхід ніби переносить виконавця у минуле (за допомогою теоретичного вивчення історично-суспільних подій, музичного виконавства, композиторської творчості та ін.).

Цей підхід є дещо схожим на «класично-романтичний» (спирання на романтичне виконання барокової музики) та «історичний» (спирання на традиції) підходи до виконавського напряму, де найяскравіша відмінність полягає у ставленні до нотного тексту та в інструментальному виборі виконання. М. Друскін досить скептично ставився до перспективи відродження звукового простору іншої епохи, адже, як зазначалось вище, в умовах теперішнього часу ми не можемо осягнути абсолютно точного виконання старовинної музики, що пов'язано зі зміною комунікативно-творчої ситуації та історичною дистанцією.

Шо стосується сучасного музичного мистецтва, то з позицій автентичності центральними стають поняття авторського стилю та оригінальної ідеї. Це ставить перед виконавцем 
завдання іншого значення, що пов'язано зі зміною музичної лексики, стилістики, появою новаторських технічних засобів та відсутністю/скороченням історичної дистанції. Автентика у сучасній музиці виявляється більше з психологічно-особистісної (оригінальність композиторського стилю та виконавського прочитання як творча самоактуалізація) та текстологічної (твір як автентичний феномен) сторін.

Виходячи з традиційної інтерпретації поняття автентики, можна допустити, що цей термін доцільний тільки у процесі виконання старовинної музики. Проте, як сказано вище, автентичність виявляється у ціннісно-смисловому виконанні, що можливе не тільки у бароковій музиці. Сучасна музика також вимагає розуміння композиторського задуму, індивідуального виконавського осмислення, органологічної адаптації, особистісного погляду та творчого підходу виконавця. Це наштовхує на міркування про те, що виконавська автентичність у широкому розумінні є у всіх жанрах та напрямах, де жанр у перекладі з французької «genre» - манера, різновид, який має низку змістовних особливостей. Додамо, що жанр - це «оригінальна манера», завжди автентична, яка має своє ціннісно-семантичне наповнення. За М. Бонфельдом, «жанр - це одна 3 найбільш розповсюджених загальноестетичних категорій. Властивість жанру - завжди оновлюючись, зберігати своє минуле - визначило його як зосередження творчої пам'яті (Бахтін)» [3, с. 77]. Тобто жанр оновлюється у новому часовому просторі, в іншій комунікативній ситуації, однак не втрачає рис минулого, є культурним надбанням, історичною пам'яттю. «Жанр у музиці - найбільш сконцентроване, закріплене в історичному часі і в цілісній єдності поєднання окремих ознак художньої дійсності [3, с. 77]. Таким чином, жанр набуває рис культурно-естетичної діалогічності та об'єднує період написання музики і період іiі виконання (старовинна музика), постає цілісністю ознак художньої дійсності. М. Бонфельд писав, що знання музичних жанрів - це дорога до осягнення смислу музичного твору [3, с. 78]. Так, жанр є семантичною ланкою, яка активізує автентично-творчу діяльність. Це приводить до утворення таких понять, як «жанрова автентичність», «часова (історична) автентичність», «смислова (стильова) автентичність».

Як бачимо, автентично-творча активність у процесі відтворення сучасної музики виявляється у цілісності авторського 
стилю, виконавського розуміння та оригінальності ідей. Авторський стиль постає як цілісна система художньо-естетичних ознак музичної лексики; виконавське розуміння як сукупність особистісних інтенцій, прагнень, виражених у відтворенні нотного тексту; оригінальність ідей - як інсайт/ осяяння. Загалом, автентичне виконання - це жива художня подія, наділена духовним смислом.

Висновки статті дозволяють визначати автентичність як основу акордеонної виконавської творчості, яка ставить складні художні завдання і творчі інтенції. Ними є цілісність когнітивного розуміння, смислу та створення живої художньої події, де виконавець стає автором. Автентичність визначається виконавським проживанням музичного твору, духовно-естетичною спрямованістю творчих дій та оригінальністю інтерпретації. Безумовно, кожна виконавська інтерпретація особлива, оскільки виконавець як автор та особистість посідає своє єдине та неповторне місце у творчості та житті. Вищесказане дозволяє говорити, що ці творчі підходи та концепції спрямовують на визначення явища автентичності як актуальної категорії сучасного музичного виконавства, зокрема акордеоністики як нового напряму музикознавчої науки.

\section{СПИСОК ЛІТЕРАТУРИ}

1. Бахтин М. Автор и герой в эстетической деятельности. Эстетика словесного творчества. 20-ое изд. Сост. С. Бочаров. Прим. С. Бочарова и С. Аверинцева. Москва : Искусство, 1986. С. 9--191.

2. Бахтин М. Эстетика словесного творчества: 2-ое изд.; сост. С. Бочаров; прим. С. Аверинцева и С. Бочарова. Москва : Искусство, 1986. 445 с.

3. Бонфельд М. Музыка. Язык. Речь. Мышление: (Опыт системного анализа музыкального искусства). Ч. 1. Тезисы. Москва : МГЗПИ, 1991. 125 с.

4. Выготский Л. Психология искусства. Москва : Искусство, 1968. $576 \mathrm{c}$.

5. Выготский Л. Мышление и речь: Изд. 5, испр. Москва : Лабиринт, 1999. $352 \mathrm{c.}$

6. Гадамер Х.-Г. Истина и метод. Основы философской герменевтики. Москва : Прогресс, 1988. 637 с.

7. Друскин М. Йоганн Себастьян Бах. Москва : Музыка, 1982. 384 c.

8. Ландовская В. О музыке. Москва : Радуга, 1991. 440 с.

9. Маслоу А. Мотивация и личность. Санкт-Петербург : Евразия, 1999. $478 \mathrm{c.}$ 
10. Роджерс К. Исскуство консультирования и терапии. Москва : Эксмо, 2002. 976 с.

11. Харнонкурт Н. Музика як мова звуків: науково-популярне видання. Суми : Собор, 2002. 184 с.

\section{REFERENCES}

1. Bakhtin M. (1986) Author and hero in aesthetic activity. M. M. Bakhtin. Aesthetics of verbal creativity. 20'th ed. comp. S. Bocharov. Note S. Bocharova and S. Averintseva. M.: Art. [in Russian].

2. Bakhtin M. (1986) Aesthetics of verbal creativity: 2'nd ed.; comp. S. Bocharov; approx. S. Averintseva and S. Bocharova. M.: Art. [in Russian].

3. Bonfeld M. (1991) Music. Language. Speech. Thinking: (Experience of systematic analysis of musical art). Part 1. Abstracts. M .: MGZPI. [in Russian].

4. Vygotsky L (1986) Psychology of art. M.: Art. [in Russian].

5. Vygotsky L. (1999) Thinking and speech: Ed. 5, ref. M.: Labyrinth. [in Russian].

6. Gadamer H.-G. (1988) Truth and method. Fundamentals of philosophical hermeneutics. M.: Progress. [in Russian].

7. Druskin M. (1982) Johann Sebastian Bach. M .: Music. [in Russian].

8. Landovskaya V. (1991) About music. M .: Raduga. [in Russian].

9. Maslow A. (1999) Motivation and personality. SPb: Eurasia. [in Russian].

10. Rogers K. (2002) The Art of Counseling and Therapy. M .: Eksmo. [in Russian].

11. Harnonkurt N. (2002) Music as a language of sounds: popular science publication. S.: Sobor. [in Ukrainian]. 